\title{
Editorial: the future of scientific publishing
}

\author{
Koen Martens
}

Published online: 27 February 2008

(C) Springer Science+Business Media B.V. 2008

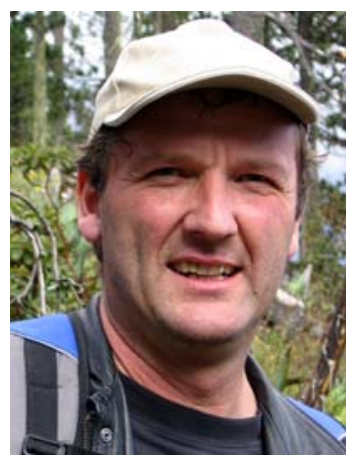

Koen Martens

Editor-in-Chief

You are now consulting Volume 600 of Hydrobiologia. It has just appeared, in the middle of a fastchanging world of scientific publishing. A mere 10 years ago, scientists wrote a manuscript, put three hard copies in an envelope and submitted it to a journal. Subsequently, if all went well, it was accepted, publishers printed the paper, libraries bought the journals and scientists spent a few hours every week in the library going through newly arrived journals, and that was that, nothing to it, everybody happy. Or were they?

K. Martens ( $\square)$

Royal Belgium Institute of Natural Sciences,

Brussels 1000, Belgium

e-mail: koen.martens@naturalsciences.be
In a relatively short period of time, many more and different opportunities have arisen for authors, libraries and publishers. For starters, nearly all international journals now have online submission and web-based editorial systems. More hidden from authors, but not of any less interest to them, is the streamlined production process, almost invariably outsourced and using uniform software systems. Librarians also saw their metier changing fast: they had to adapt to the fact that there were significant shifts from paper to online consultation of journals (and one may well ask if paper versions of journals are doomed), as well as from library-based funding of publication (journal subscriptions) to pay-per-paper in open-access forums. In addition, rather than sell individual journals to individual libraries, publishers now like to sell large packages of journals (a 1,000 titles or more) to a consortium of users, for example the consortium of Canadian universities.

What has all this meant to members of the scientific communities at large, who are, simultaneously, authors, referees and readers? For you also, times have been $a$-changing. The most considerable of these over the last 10 years, I dare guess, have been an increased work load, higher pressure to produce, and a decrease in time available to do what you are generally paid to do: to think! This has resulted in some measurable effects. First, there is a common decrease of what constitutes "the least publishable unit", because authors are forced to publish more and to do so in higher ranked journals. 
Second, journal editors find that there is an increased reluctance for colleagues to act as referees. It is nowadays not uncommon that an editor has to invite 10 or more referees to obtain one or two reports. Although academics lately often have to prioritise daily tasks ruthlessly (students and (project) administration first, research and publishing second, family and health an unhealthy third place, and refereeing, yes well, refereeing ...), Perrin (2008) calculated that a scientist publishing an average of 3-4 papers needs to referee $12-16$ papers a year, if he or she wants to 'pay back' what the scientific community has done for him or her. Third, there is change in perception of the value of impact factors. Amongst other hiccups, the well-publicised inability of Thomson's ISI to provide the basic data on which impact factors of three well-known journals were based (Rossner et al., 2008) have made many people sit up and take notice. It appears that several alternative initiatives are now in the pipeline, of which the H-index might be the best known to date. Some competition among measurements of bibliographic importance, which have such an impact on our academic lives (forgive the pun), is more than welcome (Butler, 2008).

This brings us back to the present Volume 600 of Hydrobiologia. Since I started as Editor-in-Chief with Volume 500, not even five years ago in September 2003, I have lived through these accelerating changes and I could not help to think on occasion of that old Chinese curse: "may you live in interesting times" (then, mostly, times of war) ... Indeed, the job was never boring over the past years.

Since 2003, Hydrobiologia has seen its submissions for regular volumes increase by an annual $20 \%$ to about 800 manuscripts in 2007 . We have been able to accept about $25-30 \%$ of these. In addition, our journal publishes between 10 and 15 special issues per year (comprising an additional 250 or so papers), the scientific and technical requirements of which now match these of the regular issues. Hydrobiologia published 6,348 pages in 2007 and 7,620 pages in 2006. Libraries truly get value for money, as this is much more than the c.5500 pages that normally comprise an annual subscription! Hydrobiologia is, indeed, the "aquatic library".
The time between submission and acceptance has generally decreased significantly, and in some cases (including refereeing and revision) was less than one month. This is, of course, owing to the online submission system or Editorial Manager, and because of the direct involvement of the editorial board. The board of Hydrobiologia has expanded considerably and has attracted many new enthusiastic specialists in a wide range of fields. Our editors have truly become associate editors and they ensure that your manuscripts receive expert attention.

Access to papers has been enormously facilitated by a range of publishers' initiatives, from alerting services for newly published volumes to Online First access as soon as papers are accepted and corrected proofs have been received. And also do not forget that Hydrobiologia can now be consulted online, 24 hours a day and 7 days a week, on no less than 10 million desktops across the world!

All of this ensures that Hydrobiologia now uses high-quality standards which have led to increased appreciation of the journal by authors, as well as by readers, resulting in an increase of the impact factor from 0.65 in 2003 to 1.049 in 2006-satisfyingly above the psychological barrier of 1 .

And finally, we hope that you like the new covers of the printed volumes!

The future is, more than ever, difficult to predict, as the market of scientific publishing is so volatile. Nevertheless, one certainty must remain: as long as a journal ensures maintenance of high scientific standards first and foremost amongst its objectives, the future will be bright. We invite you to contribute to that future with Hydrobiologia.

\section{References}

Butler, D., 2008. Free journal ranking tool enters citation market. Nature 451: 6 .

Perrin, W. F., 2008. In search of peer reviewers. Science 319: 32.

Rossner, M., H. Van Epps \& E. Hill, 2008. Show me the data. Journal of Cell Biology 179: 1091-1092. 